\title{
Micromorphology of Salt Glands and Content of Marker Compound Plumbagin in the leaves of Plumbago zeylanica Linn
}

\author{
Madathilparambil Vasu Sudhakaran*
}

\section{Madathilparambil Vasu Sudhakaran*}

Associate Professor, Academic Staff College, University of Calicut, Malappuram -673635, Kerala, INDIA.

Correspondence

Dr. Madathilparambil Vasu Sudhakaran

Associate Professor, Academic Staff College, University of Calicut, Calicut University PO, Malappuram - 673635, Kerala, INDIA.

Phone no : +91-9447500125

E-mail: dr.sudhakaranvasu@gmail.com

\section{History}

- Submission Date: 28-08-2018;

- Review Completed: 02-10-2018:

- Accepted Date: 20-11-2018

DOI : 10.5530/pj.2019.1.27

Article Available online

http://www.phcogj.com/v11/i1

\section{Copyright}

(c) 2019 Phcog.Net. This is an openaccess article distributed under the terms of the Creative Commons Attribution 4.0 International license.



\begin{abstract}
Background: Salt glands are highly specialized epidermal structures developed in recretohalophytic plants, intended for salt storage (reservoir) and as a means to alleviate the salt stress of the saline habitat by exo-recreto releases excess salts from the mesophyll tissues to the surrounding environment. Plumbago zeylanica Linn belongs to the family Plumbaginaceae is an important medicinal plant and espoused as a source for the drug Chitraka. Aim: The present study concerns the delineation of micromorphological characteristics of the paradermal and cross sections of the leaf epidermis, lamina, salt glands, petiole and mucilage secreting glands of the calyx of the flowers of Plumbago zeylanica Linn. Materials and Methods: Delimiting the morpho-histological profile of the leaves and to develop the chromatogram of the methanol extract of the leaves and quantification of the marker compound plumbagin in the leaves using High Performance Thin- Layer Chromatographic (HPTLC) method. Results: Distribution of uniseriate, cruciate type clothing trichomes, characteristic contour of midrib, presence of amphistomatic epidermis with anisocytic stomata, crystals in idioblast of ground tissues of petiole and mesophyll, large palisade ratio, small stomatal index, multicellular salt gland structure with 8 cells, cuticular secretory cells, crescent shaped petiole, densely distributed mucilage secreting glands on the calyx of flowers were features characteristic of the taxon. The HPTLC finger printing profile of the leaves revealed six phyto-constituents. Densitometric scanning of plumbagin had shown the absorption spectra $\lambda_{\max }$ at $270 \mathrm{~nm}$. Spectral matching by overlaying the absorption spectra of standard marker compound with the phyto-constituents present in the methanol extract of sample could fail to obtain any spectral matching at $\lambda_{\text {max }} 270 \mathrm{~nm}$, suggestive that dried leaves of P. zeylanica did not contain any appreciable amount of Plumbagin. Calibration data obtained by polynomial regression had revealed that dried leaves of $P$. zeylanica Linn contained below $105 \mathrm{ng} / \mathrm{\mu l}$ of plumbagin in methanol extract of leaves.
\end{abstract}

Key words: Salt glands, Absorption spectra, Chromatogram, Halophytes, Stomatal index, Plumbagin.

\section{INTRODUCTION}

Soil salinity is an important abiotic stress factor that affects the very survivability of plants and thus virtually all angiosperm species are naturally sensitive to saline environment except a small group which represents about $0.25 \%$ of the world's flora ${ }^{1}$ called halophytes (salt tolerant plants). Halophytes are both structurally and functionally conversant to mitigate the abiotic stress of saline habitat, adapted to grow and complete their life cycle. Amongst these halophytes, recretohalophytes, a sub group of halophyte comprising of about 370 species $^{2}$ world over have developed specialized morphological structures on the surface of the aerial parts particularly on leaves through which excess ions are secreted to the outside of the plant. The most remarkable morphological features of recretohalophytes are the salt-secreting salt glands and salt bladders.

Halophyte comprises eleven families ${ }^{3}$ that are taxonomically not related; amongst them the main dicotyledons are Amaranthaceae, Plumbaginaceae,
Plantaginaceae, Aizoaceae and Brassicaceae. However recretohalophytes have been described structurally under four types. Which include unicellular secretary hairs found in Porteresia of Oryzoideae subfamily, bicellular glands of the chloridoid grasses of Poaceae family; multicellular glands in Frankinaceae, Plumbaginaceae and Tamaricaceae on one hand and Primulaceae, Acanthaceae and Oleaceae families on the other; and salt glands are of salt bladder (specialized large vacuolated epidermal cells) type found in Oxalidaceae, Chenopodiaceae and Mesembryanthemaceae family. ${ }^{3-4}$ Though salt gland structure have significant variation among the different species, their phylogenetic distribution in taxonomically unrelated taxa provide unstinting support to the concept that the salt glands are originated independently in multiple times during the course of evolution, as a convergent means of evolution for a common adaptive device ${ }^{4-8}$ to circumvent 
the abiotic stress of saline habitat. In the functional point, there are two types of recretohalophytes, the exo-recretohalophytes that excrete salt through salt glands to the surface of the leaf and endo-recretohalophytes which collect salt in the vacuole of specialized bladder cell and sequester the excess salt through the rupture of salt bladders. ${ }^{9}$

Genus Plumbago (Plum-Bay-go) of the family Plumbaginaceae is a cosmopolitan halophytic taxon comprised of about 17 species all over the world, three species are found distributed in India namely P. zeylanica Linn, P.indica Linn and P.capensis Thunb. Plumbagin is the major active principle and therapeutic compound of Plumbago species. In Indian system of medicine, P. zeylanica Linn is espoused as source for the drug Chitraka, which is one of the major ingredients in many Ayurvedic formulation. ${ }^{10}$ Although some previous studies have reported that the salt glands in the Plumbaginaceae (Plumbago europaea; P.capensis; Limonium latifolium; Statice gmelin) exo-recreto discharge salt from the aerial parts of shoot, particularly from the leaf however, a clear evidence for this phenomenon has not previously been reported in P. zeylanica Linn. Since the material occurrence of salt glands not cosmopolitan amongst plants and are limited to a few taxa of diverse angiosperm families, together with the sparse distribution of salt glands in epidermal tissues (only a few epidermal cells of leaf possessing the salt glands) even in those accessible taxa, the reports on the investigation of salt glands are lacking in literature, barring a few cases. ${ }^{6,-13}$ In addition to this, the foliar architecture and histological components of the leaf are being considered as satisfactory parameters for species identification in botanical pharmacognosy, the present investigation has been undertaken with the objectives of delineating the leaf anatomical characteristics of Plumbago zeylanica using light and polarized microscopy and quantification of bio-marker compound Plumbagin in the leaves by HPTLC methods.

\section{MATERIALS AND METHODS}

\section{Materials}

Plumbago zeylanica Linn is a perennial spreading shrub attains a height up to $1-1.5 \mathrm{~m}$ (Figure 1 and 1a) and grows in salty, dry places or coastal habitat. Leaf are simple, membranous, alternate, lamina is broadly cordate at the base, acuminate at apex with entire margin. Leaves contained the salt or chalk secreting glands. Flowers are pentamerous, occur in cluster in spike like racemes at the tip of branches (Figure 2). Flowers are white in color (Figure 2a), calyx is persistent, tubular with five lobes and sticky, covered by many mucilage secreting emergences on their surfaces.

\section{Methods}

Micro-morphological profile was made on leaf epidermis, lamina and petiole and calyx. P. zeylanica Linn for the present study was collected from the natural habitat of Thiruvananthapuram District of State of Kerala and identification and authentication were done using Gamble's Flora of Presidency of Madras. Fine hand sections of transverse and paradermal planes of the leaves were taken using the standard procedures. Sections were stained with aqueous Safranin $1 \%$ and mounted in glycerin. The investigation on macroscopic and micromorpho diagnostic profile of the specimens were undertaken by using Olympus Microscope (Model CX 41; Tokyo, Japan) with CCD camera 2 Mega Pixel and quantitative measurements were taken using Olympus Image-Pro Plus, version 5.1 software and stereo and polarized microscope. Cleared leaf was used for analysis of venation pattern. The pulverized powder of the leaves was kept in a labeled, air tight glass container for the preparation of TLC plates and densitometric scanning of the chromatogram.

\section{Development of Chromatogram by HPTLC method Chemicals and reagents}

Aluminum plate $(20 \times 10 \mathrm{~cm})$ pre-coated with silica gel $60 \mathrm{~F}_{254}$ (Merck) of uniform thickness was used as adsorbent. Analytically pure standard Plumbagin procured from Sigma and solvents of HPLC/ Chromatographic Grade procured from Merck and Qualigens Fine Chemicals, India were used.

\section{Sample preparation and Chromatographic conditions}

Accurately weighed 1.5 gms of leaf powder of $P$. zeylanica Linn was refluxed in $25 \mathrm{ml}$ of Methanol. Extract obtained was filtered using Whatman filter paper and transferred to a volumetric flask and volume was made upto $10 \mathrm{ml}$ with methanol. The chromatographic separation of analytes was achieved by using the mobile phase consisted of $n$-hexane: ethyl acetate in the ratio $(8: 2 \mathrm{v} / \mathrm{v})$. The standard stock solution $10.5 \mathrm{mg} / \mathrm{mL}$ of plumbagin was prepared in HPTLC-grade methanol. For the HPTLC analysis $1 \mathrm{ml}$ of this stock solution was diluted with $10 \mathrm{ml}$ of methanol and obtained a working solution of $1.05 \mathrm{mg} / \mathrm{mL}$ concentration.

\section{Instrumentation}

CAMAG HPTLC System (Switzerland) equipped with CAMAG Linomat V Automatic Sample Spotter with syringe $(100 \mu \mathrm{l})$, Twin trough glass chamber, UV cabinet with dual wavelength and the densitometer consisted of TLC scanner 3 linked to WINCATS software were used.

\section{HPTLC Methods}

For the HPTLC analyses, five different application volumes of the working solution were used in five different tracks on the pre-coated plate of Silica Gel and methanol leaf extract of the test sample in one track (Track no. 6). The spotting volume of standard working solution were 1,2,3,4 and $5 \mu \mathrm{l}$ with concentrations ranged from 1.05 to $5.25 \mu \mathrm{l} /$ band respectively and the volume of leaf extract on the plate was $5 \mu \mathrm{l}$ (ie., five standards plus one methanol extract of the leaf sample). The plate $(20 \times 10 \mathrm{~cm})$ was developed in Twin trough glass chamber, saturated with the mobile phase n-hexane: ethyl acetate $(8: 2 \mathrm{v} / \mathrm{v})$. Densitometric scanning of the TLC plate at $254 \mathrm{~nm}$ and $366 \mathrm{~nm}$ were performed using CAMAG TLC



Figure 1: P. zeylanica Linn. 




Figure 1a: P. zeylanica Linn.

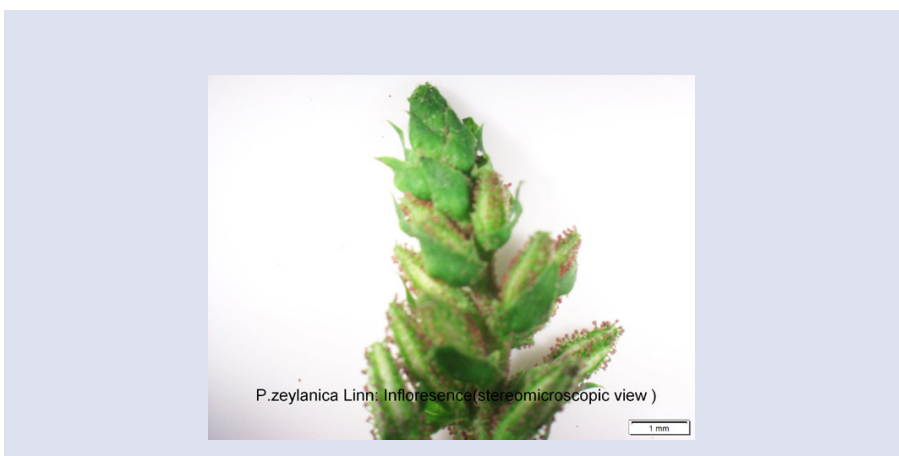

Figure 2: P.zeylanica: Inflorescence (stereo microscopic view)



Figure 2a: P. zeylanica: Flower(stereo microscopic view)

Scanner 3 and operated by the WINCATS software. Overlay spectra was plotted using the peak height of methanol extract of sample vs the standard marker compound $\lambda_{\max }$ at $270 \mathrm{~nm}$.

\section{RESULTS AND DISCUSSION}

\section{Microscopic evaluation of leaves}

Lamina was dorsiventrally differentiated into adaxial and abaxial epidermis. Both epidermises were uniseriate, composed of compactly arranged rectangular cells. Lamina was flat and much reduced in dimension compared to broad midrib. Midrib region was prominently raised laterally at the middle on the adaxial side with a broad triangular projection on the abaxial side (Figure 3 and 3a). Midrib composed of epidemics, collenchyma, mesophyll and vascular bundles. Beneath the adaxial and abaxial epidermis contained a patch of collenchyma composed of 4-5 cells wide. The size of individual adaxial epidermal cell ranged between $14.8 \mu \mathrm{m}$ to $28.2 \mu \mathrm{m}$ in length and $20.3 \mu \mathrm{m}$ to $24.4 \mu \mathrm{m}$ in width. The mesophyll was differentiated into palisade and spongy tissues (Figure $3 \mathrm{~b}$ ). There were two rows of palisade cells in adaxial side (Figure 3c) of lamina. They formed about $40 \%$ of total area of the midvein region. Cells of palisade were elongated, compactly arranged, barrel shaped and filled of plenty of chloroplasts (Figure 3c). The size of the individual palisade cell ranged from $24.6 .5 \mu \mathrm{m}$ to $41.1 \mu \mathrm{m}$ in length and $10.2 \mu \mathrm{m}$ to $17.3 \mu \mathrm{m}$



Figure 3: P. zeylanica: T.S. of Lamina through midrib (x 2).



Figure 3a: P. zeylanica: T.S. of Lamina through midrib (x 4)



Figure 3b: P. zeylanica: T.S. of Lamina (x 10) 




Figure 3c: P. zeylanica: T.S. of Lamina (x 40).



Figure 4: P. zeylanica :Adaxial stomata (x 40).

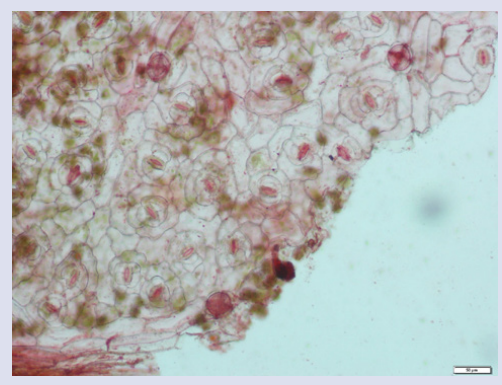

Figure 4a: P. zeylanica: Adaxial stomata (x 10).

width. The palisade cell index (length/width ratio) was found to be 3:1 and the palisade ratio 6 . Number of palisade cells per square millimeter of mesophyll tissues was found to be 2090. Abaxial side of the lamina was occupied by spongy tissues, consisted of 2-3 layers of cells and occupied $60 \%$ of the areas of mesophyll. The size of the individual spongy cell ranged from $12.2 \mu \mathrm{m}$ to $20.1 \mu \mathrm{m}$ in length and $14.2 \mu \mathrm{m}$ to $17.3 \mu \mathrm{m}$ width. Crystal idioblast was found in both palisade and spongy tissues. Size of prismatic crystals of calcium oxalate ranged the dimension from $8.8 \times 6.3 \mu \mathrm{m}$ to $7.2 \times 12.2 \mu \mathrm{m}$. A series of free collateral vascular strands were found embedded in the mesophyll tissues.

\section{Epidermal characters}

Leaves are amphistomatic with contained anisocytic stomata (Figure 4, $4 \mathrm{a}, 4 \mathrm{~b}$ and $4 \mathrm{c}$ ) on both surfaces. There were more stomata on the abaxial than on the adaxial surface and the stomatal distribution was random.



Figure 4b: P. zeylanica: Abaxial stomata (x 10).



Figure 4c: P. zeylanica: Abaxial stomata (x 10).

The mean length and breadth of adaxial stoma was found as $26.5 \mu \mathrm{m} \mathrm{x}$ $20.1 \mu \mathrm{m}$ and abaxial stomata 28. $1 \mu \mathrm{m} \times 18.4 \mu \mathrm{m}$ and Guard cell area (GCA) was found to be $404 \mu \mathrm{m}^{2}$ and $392 \mu \mathrm{m}^{2}$ for adaxial and abaxial surface respectively. The mean number of adaxial epidermal cells per square millimeter area of leaf was found to be 1218.8 and that of abaxial epidermal cells was 1117.5. The stomatal index calculated for adaxial and abaxial surface was found to be 10.4 and 8.6 respectively. Some of the epidermal cells bear uniseriate, cruciate type trichomes on both surfaces. The wall of outer epidermal cells were uniseriate and moderately cuticularised $(>2 \mu \mathrm{m})$. Anticlinal walls of both adaxial and abaxial epidermal cells were straight (Figure 4 and $4 \mathrm{a}$ ).

\section{Microscopic evaluation of salt glands}

Salt glands of $P$. zeylanica were found on the epidermal axials of both adaxial and abaxial surfaces of the leaves and were exo-recreto type. The epidermal cells of the leaf axials undergo sucessive cell divisions which lead to a slighly protruded multicellular configuration of closed gland on the epidermis in which cells are arrenged in a rosette fashion.

\section{Paradermal section of leaf epidermis}

The paradermal section (top view) of the adaxial leaf showed that salt glands were found distributed in the whole surface along with stomatal apparatus (Figure 4a). The salt gland structure of $P$. zeylanica comprised of 8 cells (Figure 5, 5a, 5b and 5c). Amongst the 8 cells, four were secretary cells located towards the interior of gland structure, which were subtended or encircled by accessory cells. Accessory cells include collecting cells and basal cells. The whole structure of the multicellular gland resembles a cup with circular rim as the limit of secretory chamber (Figure $5 \mathrm{c}$ ). The micro-morphology of the salt glands delineated in the present study is seemed to be similar in configuration of the ultrastructure 


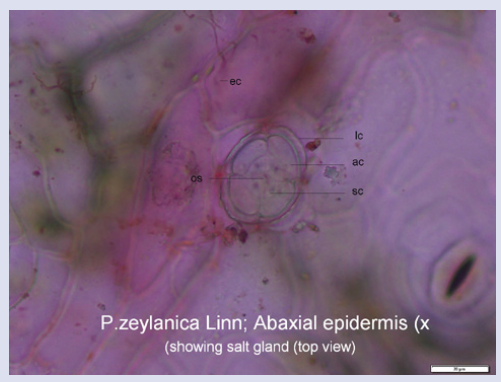

Figure 5: P. zeylanica : Salt gland top view $(x$ 40)

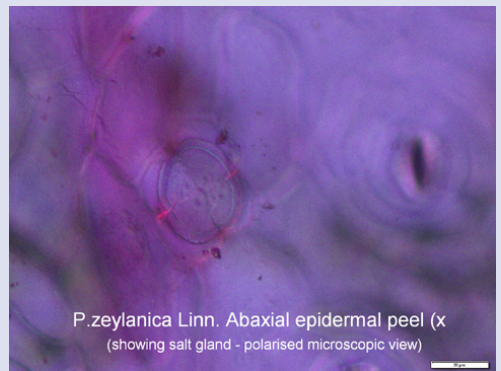

Figure 5a: P. zeylanica: Abaxial epidermis: salt gland (polarized microscope $x$ 40).



Figure 5b: P. zeylanica: Salt gland in upper lamina (x 40)

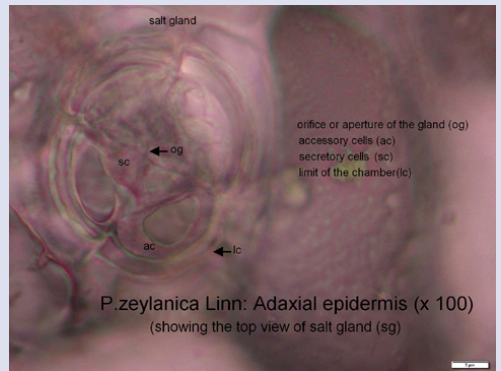

Figure 5c: P. zeylanica : Adaxial epidermis: salt gland (x 100).

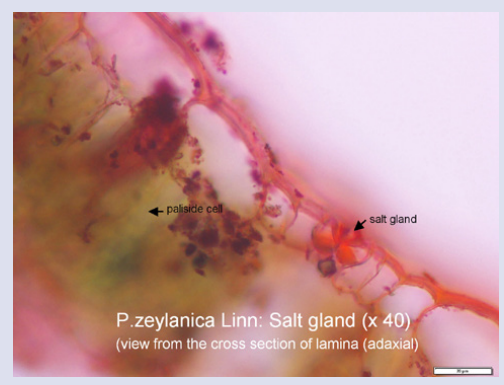

Figure 5d: P. zeylanica :Adaxial salt gland: cross sectional view ( $\mathrm{x}$ 40).

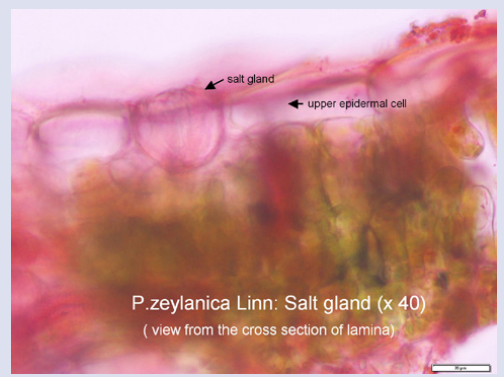

Figure 5e: P. zeylanica : Salt gland: cross sectional view (x 40).

of the salt gland of Plumbago aureculata delineated by Grigore and Toma. ${ }^{14}$ Some taxa of other closely related families in Caryophyllales also reported to have contained the same core structure of Plumbago salt glands with slight modification. ${ }^{14}$ They include the multicellular salt gland structure with 8 celled configuration in Limonium gmelini (family Plumbaginaceae) and salt gland with 8 secretory cells in the Tamarix (T. aphylla, T. pentandra, T. ramosissima and T. mannifera) and gland with 6 secretory cells in Frankenia (F. floribunda, F. pulverulenta, F. laevis, $F$. intermedia and $F$ reuteri). This diversity in salt gland structure of caryophylleles may be suggestive of the result of convergent evolution occured in different time periods among these taxa, for the common cause to circumvent the saline habitat. ${ }^{15}$ In present study the average dimension of the individual salt gland was measured as $35.5 \times 31.4 \mu \mathrm{m}$ and $33.2 \times 29.4 \mu \mathrm{m}$ and two dimensional surface area was found to be $811.3 \mu \mathrm{m}^{2}$ and $888.7 \mu \mathrm{m}^{2}$ for the adaxial and abaxial salt glands respectively. Figure $5 \mathrm{~b}$ depicts of the top view of salt gland, seemed to exudate salt through the orifice of the secretory cells, which precipitate and deposited as chains of crystals on the epidermal surface.

\section{Cross section of salt gland}

Cross sectioning of samples to be obtained the desired plane of sections containing the salt glands was quite difficut and challenging, since the salt glands were found sparsely distributed in epidermal tissues of the lamina. The cross sectional view of the salt gland (side view) had further revealed that the walls of the secretory cells completely covered by thick cuticle which extends down to the sides of the secretory cells and subtendending to the basal collecting cells. The cuticular chamber thus formed acts as a reservoir for salt storage. Secretory cells contained pore or aperture through which salt exude out of the lamina. The entire structure of gland appeared sunken (Figure $5 \mathrm{~d}$ and $5 \mathrm{e}$ ) in paliside mesophyll tissues. Figure $5 \mathrm{e}$ depicts the side view of salt gland, showing that the 
walls of secretory cells slightly protrude out and the closed configuration of gland resembles a cup, in which layers of transverse septa seemed to be separating the cells of the salt gland.

Salt glands represent only a relatively small proportion of epidermal tissues of lamina of recretohalophyte and the salt secreting mechanism of salt glands are not fully known. However it was reported that the collecting cells create a salt efflux gradient in the chamber, thus collects salts from the neighboring mesophyll cells through plasmodesmata connection and transport the salt to the secretory cells. Secretory cells exudates salt and other mineral substances into the outer environment through the orifice or aperture of secretory cells. The cuticular envelope of secretory cells prevents the leakage of salt back into the neighboring mesophyll tissues via apoplast. ${ }^{16-17}$ The number of secretory cells possessing the gland and density of salt glands are genetically determined and species specific however, their number per unit leaf area are somewhat equal for both adaxial and abaxial surfaces and generally much fewer than stomata. In the present study the mean number of salt glands per square millimeter area of leaf was found to be $6.96\left(6.96 / \mathrm{mm}^{2}\right)$ and 5.02 $\left(5.02 / \mathrm{mm}^{2}\right)$ and stomata to salt gland ratio was found to be $16: 1$ and 15.1 respectively for adaxial and abaxial leaf epidermises. Density of salt glands observed in the present study was found to be much lower than the related taxa of plumbaginaceae described in Plumbago capensis, P.europaea and Limonium latifolium and Statice gmelin by Grigore and Toma. ${ }^{18}$ In Limonium species of Plumbaginaceae it was reported to contained 20 to 50 salt glands per square millimeter of leaf. ${ }^{19}$

\section{Microscopic evaluation of Petiole}

In cross sectional view the petiole had dorsiventral differentiation, with a prominent groove or furrow on its ventral side (Figure 6 and $6 a$ ) with a nob like projection at its centre and whole structure appeared crescent shaped. Dorsal side of the petiole had a prominanent projection somewhat at the middle. Epidermis of petiole was uniseriate, smooth, devoid of trichome. Epidermis was followed by a layer of collenchyma cells. Beneath the collenchyma lyed, a broad zone of parenchymatous ground tissues, upper 2-3 layers of ground tissues contained abundant deposition of chlorophyll. 8-9 vascular bundles were aligned in the ground tissue (Figure 6a) with 4 main vascular bundles on the dorsal side, those on the ventral side were peripheral accessory bundles. Vascular strands were separated from one another by wide areas of ground tissues. Vascular tissues formed a continuous cylinder, with a band of periphloematic parenchymatous bundle sheath (Figure 6b, 6c and 6d) encircling each vascular cylinder. Xylem vessels are aligned in radial rows of 3-4 and phloem lies on adaxal side. The cells of parenchymatous ground tissue were large, hexagonal in shape and the corners of the intervening walls were anchored with crystal idioblasts. Idioblasts contained calcium oxalate crystals of the dimensions ranged from $9.68 \times 5.2 \mu \mathrm{m}$ x 10.6 × $6.2 \mu \mathrm{m}$, which confer mechanical support to the ground tissues.

\section{Venation pattern}

Venation patterns of cleared petiolated leaves with entire margins had shown the major leaf venation pattern of actinodromous (Figure 7 and $7 a)$ under low $(\times 2)$ magnification. Areolation was well developed and appeared hexagonal in shape (Figure $7 \mathrm{~b}$ and $7 \mathrm{c}$ ). The free ending ultimate veins of the areoles branched twice (Figure $7 \mathrm{~b}$ and $7 \mathrm{c}$ ) and marginal ultimate venation was fimbrial (Figure 7c).

Glandular secreting glands are common on the exterior surface of the calyx of flowers of Plumbaginaceae family. ${ }^{7,18}$ In Plumbago zeylanica, glandular secreting glands was found distributed in between the nerves (Figure 8 and 8a) throughout the length of the calyx tube. Calyx indumentum was glabrous in nerves (Figure 8). Outer layer of the calyx composed of uniseriate epidermis with compactly arranged rectangular

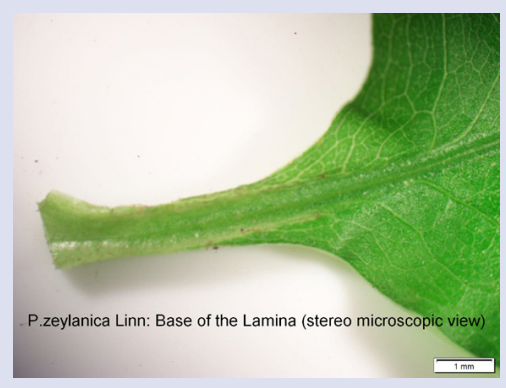

Figure 6: P. zeylanica : Base of the lamina (stereo microscopic view).

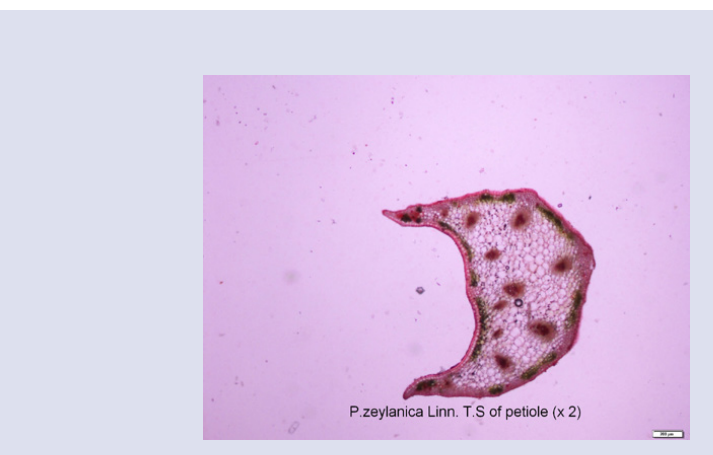

Figure 6a: P. zeylanica: T.S of petiole (x 2).

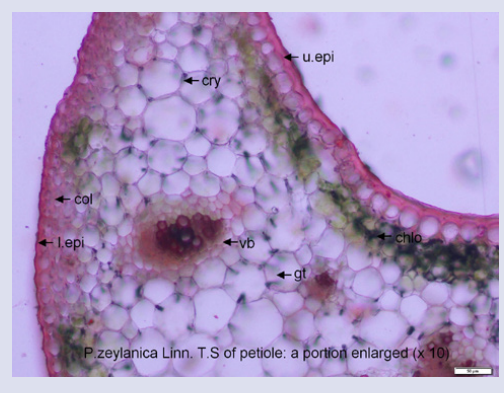

Figure 6b: P. zeylanica: T.S of petiole: a portion enlarged (x 10).

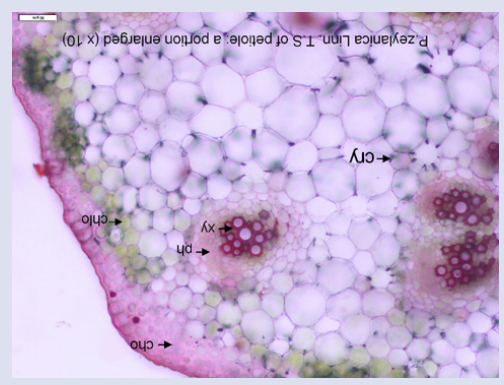

Figure 6c: P. zeylanica: T.S of petiole: a portion enlarged (x 10). 


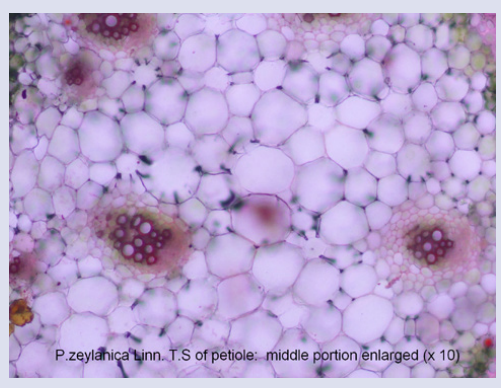

Figure 6d: P. zeylanica: T.S of petiole: a portion of middle region enlarged (x 10).

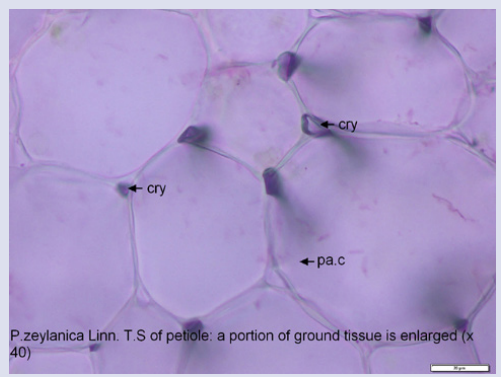

Figure 6e: P. zeylanica :T.S of petiole: a portion of ground tissue enlarged (x 40).

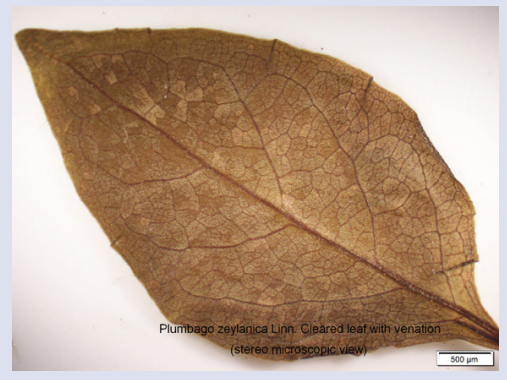

Figure 7: P. zeylanica: Cleared leaf showing venation (stereo microscopic view).

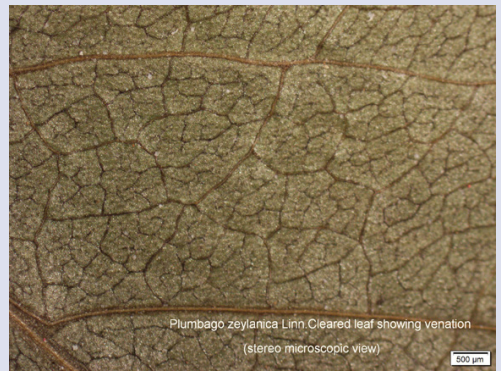

Figure 7a: P. zeylanica: Cleared leaf showing venation (stereo microscopic view)

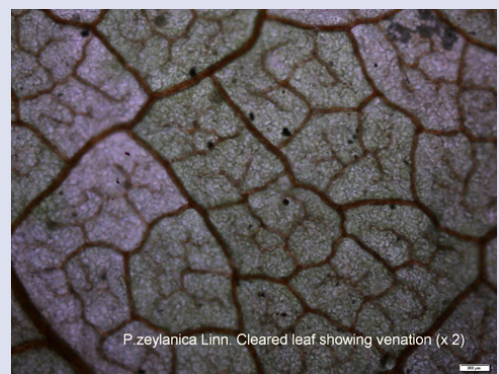

Figure 7b: P. zeylanica: Cleared leaf showing venation (x 2).

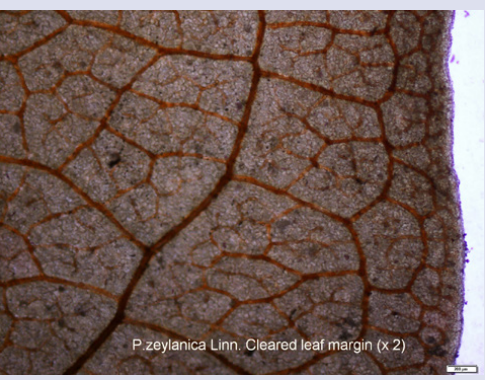

Figure 7c: P. zeylanica: Cleared leaf margin (x 2)

cells. Beneath the epidermis contained two rows of parenchymatous tissues filled with chloroplast, followed by the oval shaped multilayered sclenchyma (Figure 8b and 8c). Some of the epidermal cells of calyx bear glandular secreting trichomes as emergences at their outer surfaces. Glandular secreting trichome had a long stalk and globose head. The stalk was multiseriate and multicellular, subtending in a cuticular swollen head at the apex (Figure $8 \mathrm{~d}$ and $8 \mathrm{e}$ ). The tissue organization of the stalk includes outer uniseriate epidermis; followed by 2-3 layered elongated cortical parenchyma cells, cells were filled with abundant deposition of chlorophyll, interior towards the cortex contained 3-4 layered thin walled parenchymatous cells at the centre (Figure 8e). The swollen globose head consisted of parenchymatous secretory tissues encircled by thin cuticle, inside the head collects resineferous transparent mucilage. The cross section of calyx tube also showed small uniseriate, non- glandular clothing trichomes on the exterior of the calyx (Figure 8c) with very low density.

Glandular hairs on calyx of flower produce translucent sticky exudates however its function and advantage to plant is a disputed one. Some authors are of the view that the sticky exudates acts as a barrier for insect predators like ants, at the same time it favors the flying insect pollinators to a greater extent by preventing from the attack of predator ants and helping pollen fertility and seed dispersal..$^{20-21}$ While others are of the view that glandular hairs are homologous to glands of Nepenthes- like carnivorous plants and evolved as a mechanism to trap the visiting prey and through the secretion of digestive enzymes, kill the prey and absorb amino acids content of the insects. ${ }^{22-23}$

\section{HPTLC Finger print}

All tracks (T1 to T12) in the TLC plate were scanned at $254 \mathrm{~nm}$ (Figure 9) and the resolved bands were recorded. The Chromatogram 


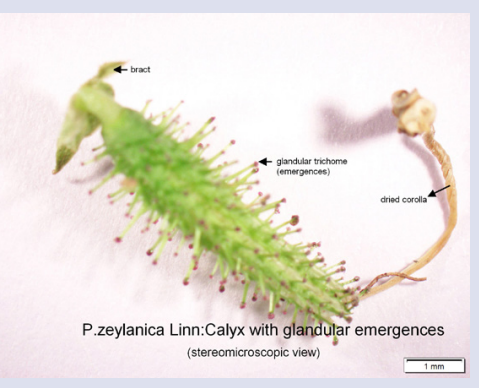

Figure 8: P. zeylanica: Calyx with glandular emergences.

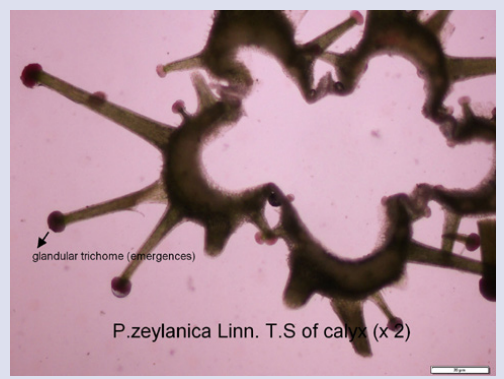

Figure 8a: P. zeylanica: T.S of calyx (x 2).

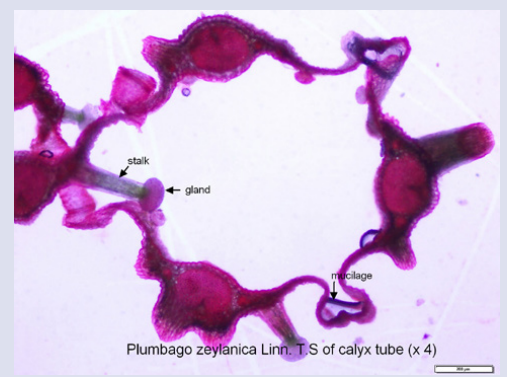

Figure 8b: P. zeylanica :T.S of calyx tube (x 4).

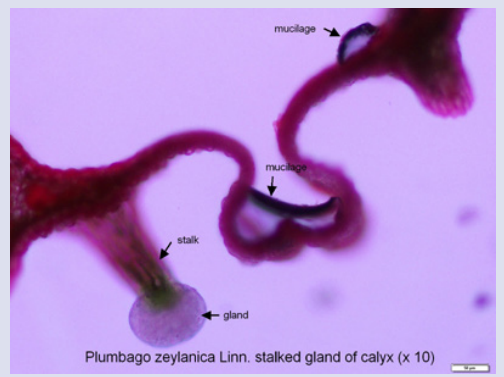

Figure 8c: P. zeylanica :T.S of calyx: a portion enlarged (x 10).

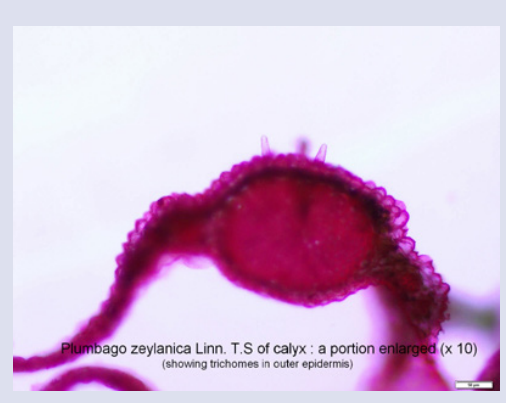

Figure 8d: P. zeylanica: Rim of calyx tube showing trichomes (x 10).

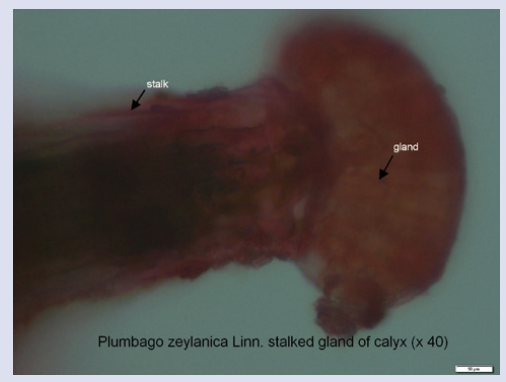

Figure 8e: P. zeylanica: Rim of calyx tube showing trichomes (x 10).

of the methanol extract of leaf had revealed six phyto-constituents (see T6 in Figure 9). Data of peak area of each resolved band of P. zeylanica leaves were recorded in track no.6 (T6) and the expressed pattern of chemical ingredient's distribution in reflection/absorption mode obtained in densitometric scanning carried out at $366 \mathrm{~nm}$ was also depicted in Figure 10.

\section{Calibration equation}

Densitometric scanning of plumbagin had shown the absorption spectra $\lambda_{\max }$ at $270 \mathrm{~nm}$. Calibration graph was plotted by polynomial method of regression, using the respective peak areas of standard plumbagin $\left(\mathrm{C}_{11} \mathrm{H}_{8} \mathrm{O}_{3}\right)$ with methanol extract of the leaves, stem and root of P. zeylanica by this author ${ }^{10}$ had reported the calibration equation as $\mathrm{Y}=178.8+91.61^{\star} \mathrm{X}+-4.825^{\star} \mathrm{X} 2$. Analysis of this calibration data ${ }^{10} \mathrm{had}$ revealed that $5 \mu \mathrm{L}$ of methanol extract of dried leaves of P. zeylanica Linn contained below $525 \mathrm{ng}(<105 \mathrm{ng} / \mu \mathrm{l})$ of plumbagin. Spectral matching by overlaying the absorption spectra of standard marker compound (concentration ranged from 9.00 to $11.00 \mu \mathrm{g} / \mathrm{band}$ ) with the phtoconstituents present in the methanol extract of sample could fail to obtain any spectral matching at $270 \mathrm{~nm}\left(\lambda_{\max } 270 \mathrm{~nm}\right)$, which may be suggestive that dried leaves of $P$. zeylanica did not contain any appreciable amount of Plumbagin (Figure 11).

\section{CONCLUSION}

The results of the present study suggest that the documented morphological descriptors and histo-anatomical markers delineated from the paradermal and cross sections of the leaf epidermis, lamina, salt glands, petiole and mucilage secreting glands of the calyx of the flowers of Plumbago zeylanica Linn could provide useful information for quality control parameters for the crude drugs. The chromatogram contains the 


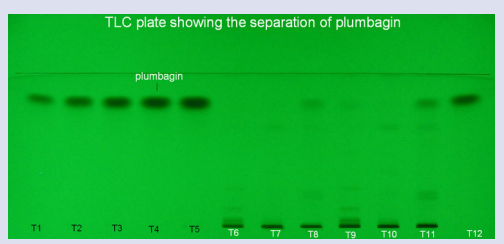

Figure 9: TLC plate scan-densitogram at $254 \mathrm{~nm}$ showing separation of plumbagin.

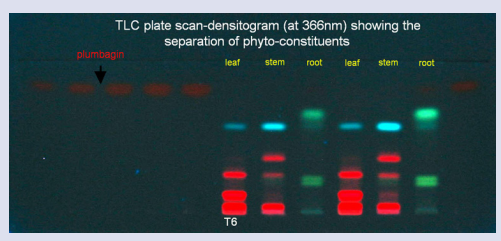

Figure 10: TLC plate scan-densitogram at $366 \mathrm{~nm}$ showing phytoconstituents.

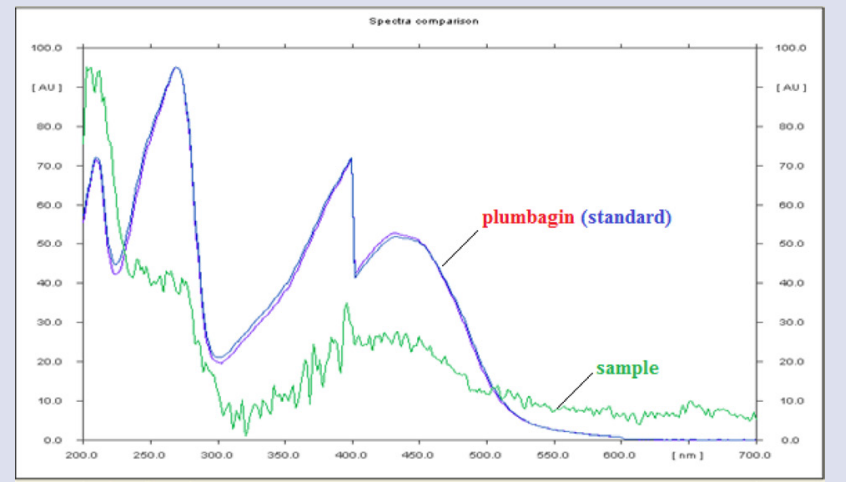

Figure 11: Overlay spectra of standard plumbagin and leaf sample at $270 \mathrm{~nm}$

expression pattern of phyto-constituents, developed in the mobile phase n-hexane:ethyl acetate $(8: 2 \mathrm{v} / \mathrm{v})$ can be used as standard procedure and the proposed method for determination of plumbagin is accurate, reliable and could effectively be used to validate the plumbagin in different commercially available formulations in market.

\section{ACKNOWLEDGEMENT}

None.

\section{CONFLICT OF INTEREST}

The author declare no conflict of interest.

\section{ABBREVIATIONS}

ABX.E: Abaxial epidermis; AC: Accessory Cells; ADAX.E: Adaxial epidermis; CHO: Collenchym; CO: Cortex; CRY: Crystal; EPI.C: Epidermal cell; EPI: Epidermis; GT: Ground tissues; LC: Limit of chamber; LEP: Lower epidermis; OG: Orifice of gland; PAL: Palisade cell; SPO: Spongy parenchyma; SC: Secretory cell; TRI: Trichome; T: Track number; T6: Track number 6; XY: Xylem; UEPI: Upper epidermis; V: Vessel; VB: Vascular bundle; VI: Vein islet; VT: Veinlet termination.

\section{REFERENCES}

1. Flowers TJ, Colmer TD. Salinity tolerance in halophytes. New Phytologist 2008;179(4):945-63. DOI: 10.1111/j.1469-8137.2008.02531.x

2. Breckle SW. Salinity, halophytes and salt affected natural ecosystems. In Läuchli A, Lüttge U, editors. Salinity: Environment-Plants-Molecules. Dordrecht, Springer. 2002;55-7.

3. Liphschitz N, Waisel Y. Adaptation of plants to saline environments: salt excretion and glandular structure. In: DN. Sen, KS. Rajpurohit (eds). Contributions of the Ecology of Halophytes. Netherlands, Springer. 1982:2:197-14. ISBN:13:97894-009-8039-6. https://www.springer.com/la/book/ 9789061939429.

4. Flowers TJ, Galal HK, Bromham L. Evolution of halophytes: multiple origins of salt tolerance in land plants. Functional Plant Biology. 2010;37(7):604-12. https:// www.publish.csiro.au/FP/pdf/FP09269

5. Faraday $C D$, Thomson WW. Structural aspects of the salt glands of the Plumbaginaceae. J Exp Bot. 1986;37(4):461-70. https://doi.org/10.1093/jxb/37.4.461

6. Dassanayake M, Larkin JC. Making plants break a sweat: the structure, function and evolution of plant salt glands. In Volkov V and Beilby MJ eds. Salinity tolerance in plants: mechanisms and regulation of ion transport. Fronters Mes: SA 2017. ISBN 978-2-88945-396-6

7. Fahn A. Secretory tissues in plants. Academic Press. 1979;41-4. ISBN0122476506

8. Naidoo Y, Naidoo G. Salt glands of Sporobolus virginicus: morphology and ultrastructure. South African J Bot. 1998;64(3):198-204. https://core.ac.uk/ download/pdf/81962051.pdf

9. Ding F, Yang J, Yuan F, Wang B. Progress in mechanism of salt excretion in recre tohalopytes. Front Biol. 2010;5(2):164-70. DOI 10.1007/s11515-010-0032-7

10. Sudhakaran MV. Histo-Chromatographic Finger Printing Profiles of the Root of Plumbago zeylanica Linn and Quantification of Marker Compound, Plumbagin. Pharmacogn J. 2017;9(6)Suppl:s77-s86. DOI : 10.5530/pj.2017.6s.161

11. Thomson WW. The structure and function of salt glands. In: Plants in saline environment eds. Poljakof- Mayber and J Gale Berlin: Springer. 1975;7-24.

12. Salama FM, El-Naggar SM, Ramadan T. Salt glands of some halophytes in Egypt Phyton. 1999;39:91-105. https://www.zobodat.at/pdf/PHY_39_1_0091-0105.pd

13. Ceccoli G, Ramos J, Pilatti V, Dellaferrera I, Tivano JC, Taleisnik E, et al. Salt glands in the Poaceae family and their relationship to salinity tolerance. Bot Review. 2015;81(2):162-78. DOI: 10.1007/s12229-015-9153-7

14. Grigore MN, Toma C. Salt secreting structures of halophytes an integrative approach. Romania: Editura Academiei. 2010;284-88. ISBN.978-973-27-194-4

15. Zhang DY, Yin LK, Pan BR. A review on the study of salt glands of Tamarix. Acta Botanica Boreali-Occidentalia Sinica. 2003;23(1):190-4.

16. Champbell N, Thomson WW, Platt K. The aoplastic pathway of transport to salt glands. J Exp Biol. 1974;25(1):61-9. DOI: 10.1093/jxb/25.1.61

17. Tan WK, Lin Q, Lim TM, Kumar P, Loh CS. Dynamic secreation changes in the salt glands of the mangrove tree species Avicennia officinalis in response to a change in saline environment. Plant Cell Enviorn. 2013;36(8):1410-22. DOI: $10.1111 /$ pce. 12068

18. Grigore MN, Toma C. Structure of salt glands of Plumbaginaceae. Rediscovering old findings of the $19^{\text {th }}$ Century: 'Mettenius' or 'Licopoli' organs?. J Plant Develop. 2016;23:37-52. www.researchgate.net/publication/311807650

19. Yamamoto A, Hashiguchi M, Akune R, Masumoto T, Muguerza M, Saeki Y, et al. The relationship between salt glands density and sodium accumulation in a wide selection from three Zoysia species. Austr J Bot. 2016;64(4):277-84 DOI:10.1071/BT15261

20. Whitney HM, Federle F, Glover BJ. Grip and slip: Mechanical interactions between insects and epidermis of flowers and their stalks. Commun Integ Biol. 2009;2(6):505-8. PMID: 20195456

21. Panicker $S$, Haridasan VK. A glimpse on insect capturing glandular hairs of Plumbago zeylanica Linn. and Plumbago auriculata Lam. Euro J Exp Biology. 2016;6(3):75-9. www. pelagiaresearchlibrary.com

22. Renner T, Specht CD. A Sticky solution: Assessing adaptations for plant carnivory in the caryophyllales by means of stochastic character mapping. Int J Plant Sci. 2011;172(7):889-901. DOI: 10.1086/660882

23. Adlassing W, LendIT, Peroutka M, Lang I. Deadly glue-adhesive traps of carnivorous plants. In: von Byern J, Grunwald I (Editors), Biological Adhesive System From Nature to Technical and Medical Application. New York: Springer. 2010;5-28. https://www.springer.com/gp/book/9783709101414 
GRAPHICAL ABSTRACT

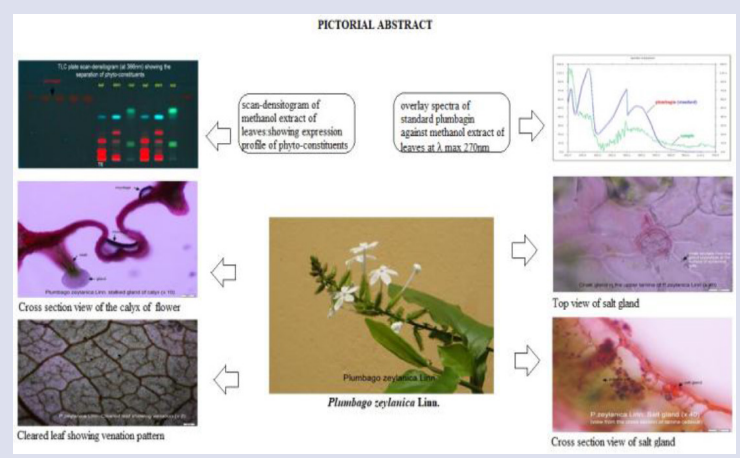

ABOUT AUTHOR

\section{SUMMARY}

- Plumbago zeylanica Linn, belongs to the family Plumbaginaceae is an important medicinal plant and espoused as a source for the drug Chitraka. The drug is being used for the treatment of various illnesses, since ancient times.

- Amphistomatic epidermis with anisocytic stomata, cruciate type clothing trichome in the epidermal tissues, distinctive contour of midrib and petiole, crystals in idioblasts, multicellular salt gland structure with 8 cells, mucilage secreting glands on the exterior surfaces of the calyx of flowers are remarkable features diagnostic of the taxon

- Densitometric scanning of plumbagin had shown the absorption spectra $\lambda_{\max }$ at $270 \mathrm{~nm}$. Calibration plot by polynomial regression had revealed that dried leaves of $P$. zeylanica Linn contained below 105 nanogram of plumbagin per microliter of methanol extract of leaves (ie., $<105 \mathrm{ng} / \mu \mathrm{l}$ ).

- The anatomical markers were delineated from the leaves of Plumbago zeylanica Linn may provide useful information for regulatory aspects of quality control measures of the crude drug materials. Chromatogram developed by HPTLC method could effectively be used to validate the plumbagin in different commercially available formulations in market.

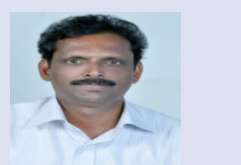

Madathilparambil Vasu Sudhakaran (M.V.Sudhakaran): Has received the Ph.D Degree from the University of Kerala. Currently he is positioned as Associate Professor, UGC-Academic Staff College of the University of Calicut. He is a research guide in Botany under the Faculty of Science. His research interests include genetic diversity analysis, genetic effects of inbreeding, and the pharmacognostical and phytochemical aspects of medicinal plants.

Cite this article: Sudhakaran MV. Micromorphology of Salt Glands and Content of Marker Compound Plumbagin in the leaves of Plumbago zeylanica Linn. Pharmacog J. 2019;11(1):161-70. 